ISSN:

Print - $2277-0755$

Online - $2315-7453$

(c) FUNAAB 2017

\title{
CHALLENGES AND CONSEQUENCES OF WATER SCARCITY: NEED FOR PUBLIC- PRIVATE PARTNER- SHIP IN KAZAURE TOWN, JIGAWA STATE, NIGERIA
}

\author{
*1A. I. ALI AND 2T. Y. RIILWAN U \\ Department of Urban and Regional Planning, Hussaini Adamu Federal Polytechnic, \\ Kazaure, Jiagwa State, Nigeria. \\ 2D epartment of G eography, Bayero University, Kano \\ *Comesponding Author:alinaira.71@ gmail.com Tel:08054813859
}

\begin{abstract}
ABST RACT
This study examined the level of water scarcity across Kazaure town, Jigawa State and the strategies employed by public and private agencies to increase their resilience toward access to affordable and safe clean water supply. Water scarcity is one of the major challenges affecting the livelihood of people in Kazaure town. The aim of the study was to examine water scarcity at micro level, in Kazaure town. A total of 1520 samples were selected which constituted $0.4 \%$ of the total population. The respondents were selected using availability sampling at water collection points of which only 1500 questionnaires were successfully returned and 20 were not. The data was analysed using simple descriptive statistics and Analysis of Variance (ANOVA) single factor. Results revealed that $20 \%$ of the sampled population has resorted to land leasing near water sources for their farming activities, 53\% has stopped dry season farming in the area of fishing, $45 \%$ of the sample respondents have stopped fishing while $56.5 \%$ indicated that they have resorted to providing their water needs by themselves. The study revealed that there are only 60 hand pump boreholes in the whole of Kazaure. The ANOVA test also indicated that there were no significant differences in terms of water sources between the settlements at 0.05 level $(P$ 0.067) and there were significant differences in terms of water facility types between the settlements at 0.05 level of significance (P 0.046). It was established from the study that water scarcity has negatively affected livelihood activities in the study area. The paper recommends that private sectors should be encouraged to pool resources together to provide and improve water supply projects and state and local government should provide more mechanical powered bore holes in the areas for effective water supply.
\end{abstract}

Keyword: Climate Change, Drinking Water, Farmland, Fishing and Water scarcity

\section{INTRODUCTION}

Clean, reliable water supplies are vital for industry, agriculture, and energy production. Every community and ecosystem on earth depends on water for sanitation, hygiene, and daily survival (Sandral, \&al., 2005), yet the world's water systems face formidable threats. Because water demand and water availability has reached critical levels in many regions of the world and there is increase in water scarcity it could be seen that by the year 2050 more than five billion people may suffer water shortages (Mancosu, \& al., 2015). So also increasing pollution contaminates freshwater and coastal aquatic ecosystem which may affect human health (Sandral 
*1A. I. ALI AND 2T.Y. RIILWANU

eal., 2005). Water scarcity affects every part of the globe, about 2.8 billion people around the world do not have access to water at least one month out of every year. More than 1.2 billion people lack access to clean drinking water (Wilhite, 2005).

A solution to water scarcity is provision of available fresh water for development. That is why the Joint Monitoring Programme for Water Supply and Sanitation set up by the World Health Organization (WHO) and United Nations Children's Fund (UNICEF) defines safe drinking water as "water with microbial, chemical and physical characteristics that meets WHO guidelines or national standards on drinking water quality." Hydrologists generally assess water scarcity by looking at a population-to-water equation that treats 1,700 cubic meters per person as the national threshold for meeting water requirements for agricultural and industrial production, energy, and the environment (World Wild Life, 2013).

Water shortage is a global issue attributed to many factors of which climate change is one of them. Climate change will exacerbate water risks, particularly as the world population grows by 50 million a year and that most recent report by the Intergovernmental Panel on Climate Change (IPCC) opines that global warming will lead to "changes in all components of the freshwater system," and concludes that "water and its availability and quality will be the main pressures on, and issues for, societies and the environment under climate change (Morrison, $\notin$ al., 2009).

Water scarcity involves water shortage, water stress or deficits, and water crisis. The relatively new concept of water stress is difficulty in obtaining sources of fresh water for

use during a period of time; it may result in further depletion and deterioration of available water resources (Lawal and Basorun, 2015). The scarcity spreads as water is needed to grow and process food, create energy, and power industry for a continually growing population. Scarcity often has its roots in water shortage, and it is in the arid and semiarid regions affected by droughts and wide climate variability, combined with population growth and economic development, that the problems of water scarcity are most acute. For the poor people, water scarcity is not only about droughts or rivers running dry, it is about guaranteeing the fair and safe access to water they need to sustain their lives and secure their livelihood.

Virtually all urban areas in Nigeria suffer water supply shortages relative to demand in one way or another. The public water supply is erratic, intermittently unreliable, and, in some cases, inaccessible, thus resulting in high dependency on supplementary sources (Lawal and Basorun, 2015). Nigeria is leading in terms of population growth in Africa and is the eighth most populous country in the world. Nigeria's population is approximately 195 million as in 2018 (Aderinto, 2018). The Nigerian community is by far the largest African community with population density of about 30,000 people per sq. Km. Kazaure town due to population growth and others challenges is facing serious water supply problems. Moreover it's a town in the semiarid region of Nigeria. Also with the existing climate change scenario, people living in Northern Nigeria will be living with high water stress by 2030 (Showers, 2002). For that Kazaure town will not be an exception. In Kazaure town, there is one major source of water that is the Kazaure dam. This dam with active storage capacity of $4,305 \mathrm{~m}^{3}$ and total volume of $299,500 \mathrm{~m}^{3}$ was designed to 
CHALLENGES AND CONSEQUENCES OF WATER SCARCITY : ...

serve many purpose among which domestic water supply is one of them but the quality of the water is said to have been deteriorating (Abubakar, \& al., 2015). These among other issues are the major challenges of water supply in Kazaure town.

Many scholars have studied water scarcity at macro level, for instance, Sunday (2015) studied fresh water scarcity induced conflicts between farmers and pastoralists in Northern Nigeria. The findings of the study showed a significant positive relationship between freshwater scarcity and conflicts among farmers and pastoralists. Kelechi (2012) studied the relationship between water scarcity awareness by transnational Nigerians and its effect on the willingness to contribute to water scarcity relief efforts in Nigeria. G usikit and Lar (2014) did a reappraisal of water scarcity and the impending water related conflicts in Nigeria, while Ishaku, \& al., (2011) studied water supply dilemma in Nigerian rural communities using review method and identified large gap in the water supply. Idowu (2017) studied causes, consequences and resolution of environmental conflict in Nigeria; he adopted frustration and aggression theory as the theoretical frameworks and found out that water scarcity was the main cause of agropastoral conflicts in Nigeria. Rilwanu, $\notin \mathrm{al}$, (2016) undertook an assessment of water supply situation in the rural areas of Kano State by conducting interviews and revealed that over $41 \%$ of the respondents stated that open wells were the major sources of drinking water in the area, $60.7 \%$ obtained drinking water from water vendors and $62.9 \%$ said water was inadequate in the area. Raunio (2016) studied successful implementation of Public-Private Partnerships to local communities providing water supply services in Sub-Saharan Africa. The re- search method was based on already published knowledge and identified that states are often poor and cannot produce water services to the citizens or to the needs of industries or agriculture. This study has a wider scope and was based on existing literature not on primary data.

It can be seen that none of these studies looked at challenges and consequences of water scarcity and all are not in the present study area. For that the need to undertake the study aroused in which the objective of the study was to investigate water scarcity in Kazaure town. It was also to identify the challenges of water scarcity and its economic consequences in the development of Kazaure town and the role of government and private sector in portable water provision.

\section{The Study Area}

Kazaure town is the headquarters of Kazaure Local Government Area which is one of the five Emirate Headquarters in Jigawa State, North West Nigeria. Kazaure town has 3 districts: Cikin-gari, Kanti and Unguwarsarki. The study area is located between latitude $12^{\circ} 4128.7^{\prime \prime} \mathrm{N}$ and, $13^{\circ} 00^{\prime} 00^{\prime \prime} \mathrm{N}$ and longitudes $7^{\circ} 50^{\prime} 00^{\prime \prime} \mathrm{E}$, 80 25'21.1"E (Isma'il, eal., 2013) (Figure 1). The total land area of the town is about $368 \mathrm{~km}^{2}$ with a population of about 161,496 but currently the population is estimated to be 380,000 peoples (Ayodele, 2000; National Bureau of Statistics, 2017). In terms of $\mathrm{G}$ eology and relief Kazaure has the highest elevations in Jigawa State with hills as high as 600 meters above sea level. Kazaure is composed of metamorphic schist called Kazaure Schist Belt (KZSB), which is part of Pan-African deformation and which led to the formation of a marginal back-arc basin floored by continental materials that accepted sediments (Szentes, 2009 and D anbatta, 2009). The vegetation of the area 
is Sudan savanna type and minimum temperature ranges from $10^{\circ} \mathrm{C}$ to $20^{\circ} \mathrm{C}$ while the maximum temperature ranges from $25^{\circ} \mathrm{C}$ to $39^{\circ} \mathrm{C}$. Mean annual rainfall is between $500 \mathrm{~mm}$ to $1200 \mathrm{~mm}$. (Ismail, \&al,
2013). Hydrology of the area is composed of river Gada Amalale and Ayuba Dam which is about $500 \mathrm{~m}^{2}$ with a height of $20 \mathrm{ft}$ ( 6.096 meters), with most of the structures made of concrete (Abubakar, $\notin a \mathrm{al}, 2015)$.

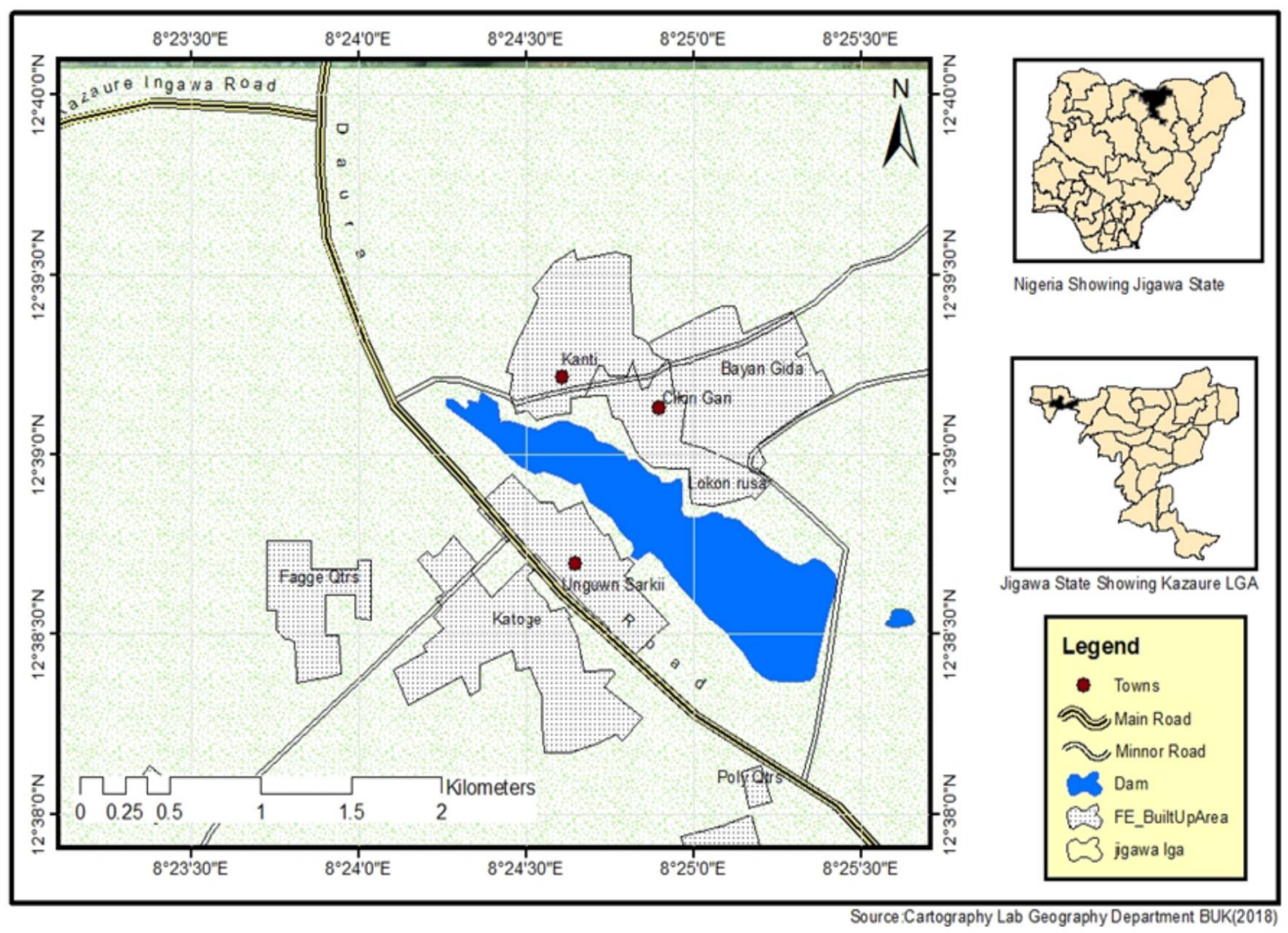

Figure 1: The study area

Source: Department of Geography, Bayero University, Kano, 2017

\section{METHODOLOGY}

\section{Methods of $D$ ata Collection}

The total population of the study area is 380,000 (National Bureau of Statistics, 2017). Out of which a sample of $0.4 \%$ was selected as a sample as adopted from Arlosorof, Gerhard, David, Andrew, Otto, and
Robered (1987) and Krejcie and Morgan, (1970). For that a total of 1,520 questionnaires were distributed to represent the entire population based on three neighbourhoods that were purposively selected, and they were Kanti, Cikin-gari, Ungunwa -sarki (Table 1). 
CHALLENGES AND CONSEQUENCES OF WATER SCARCITY : ...

Table 1. Selection of Respondents across the Selected Neighbourhood

\begin{tabular}{lllll}
\hline S/ No & Neighbourhood & Total population & Sample Size \% & $\begin{array}{l}\text { No of } \\
\text { Questionnaire }\end{array}$ \\
\hline 1 & Kanti & 64,000 & 0.4 & 256 \\
2 & Cikin-gari & 206,000 & 0.4 & 824 \\
3 & Unguwar-sarki & 110,000 & 0.4 & 440 \\
& Total & 380,000 & 0.4 & 1520 \\
\hline
\end{tabular}

Source: Field survey, 2017.

The data was collected using questionnaire and in the distribution of the questionnaire accidental sampling was adopted in which people who were available at water collection points or nearby were selected. O ut of the 1520 questionnaires distributed to the respondents only 1500 were successfully returned. Data on number of water supply infrastructural facilities were collected using check list.

\section{Methods of $D$ ata Analysis}

The data collected through questionnaire were coded in Microsoft Excel. The result was transferred to SPSS in which totals, means, and percentages of responses were determined on sources of water, agents of water provision (government, community and ppp). ANOVA tests was conducted in SPSS environment to determined level of differences in terms of common water sources among the settlements and between the three quarters (Kanti, Cikin-gari and Unguwar-sarki) and distribution of water facilities.

\section{RESULTS AN D DISCUSSION Sources of Water Supply in Kazaure}

Research findings revealed that $22.9 \%$ of the inhabitants of Kazaure obtained water from hand pump wells (Plate 1). Purchase from water vendors $22.5 \%$, from boreholes $14.9 \%$ and from river $10.3 \%$. This result is contrary to that of Rilwanu, etal., (2016) in which the major source of drinking water was borehole in Kano State Nigeria. Hand pump well appears to be the predominant source of water supply to the teeming Kazaure residents. The predominance of hand pump well in the study area may be connected to the fact that it was cheaper and easier to construct than borehole and pipe borne water. From the data (Table 2), Kanti settlement has the highest number of water vendors $(26 \%)$ and borehole (24\%). This is due to the fact that the major estate in Kazaure, which is the Shagari low Cost Estate, where majority of settlers are living. Cikin-gari has the highest responses on hand pumps 202 $(25 \%)$. This is attributed to the fact that it's a developing area and houses majority of the middle class citizens while Unguwar-sarki has the highest number of River users (14\%) and Tap users (15\%). This is because the traditional settlements are very close to the Mohammed Ayuba dam. The results of ANOVA test single factor revealed that there is no significant difference between the settlements in terms of common water sources at 0.05 level of significant since the $P$ value is $0.067, F$ value is 3.803 and $F$ critical is 4.387 (Table 3). This result is contrary to 
*1A. I. ALI AND 2T. Y. RIILWANU

that of Rilwanu, $\boldsymbol{e}$ al., (2016) in rural areas difference in terms of common water of Kano State where there was significant sources among the areas.

Table 2 Responses on the common sources of water by settlements

\begin{tabular}{|c|c|c|c|c|c|c|c|c|c|c|c|c|c|c|}
\hline \multirow[t]{3}{*}{ Settlements } & \multicolumn{14}{|c|}{ Common sources of water } \\
\hline & \multicolumn{2}{|c|}{$\begin{array}{llll} & \text { a } & \text { n } & \text { d } \\
\text { pump } & \text { well }\end{array}$} & \multicolumn{2}{|c|}{$\begin{array}{l}\text { Water } \\
\text { vendor }\end{array}$} & \multicolumn{2}{|c|}{ Open well } & \multicolumn{2}{|c|}{ Rivers } & \multicolumn{2}{|c|}{ Bore hole } & \multicolumn{2}{|c|}{ Taps } & \multicolumn{2}{|c|}{ Total } \\
\hline & $\mathrm{F}$ & $\%$ & F & $\%$ & F & $\%$ & $\mathrm{~F}$ & $\%$ & F & $\%$ & F & $\%$ & $\mathrm{~F}$ & $\%$ \\
\hline Kanti & 56 & 22 & 64 & 26 & 38 & 14 & 12 & 5 & 63 & 24 & 23 & 9 & 256 & 100 \\
\hline Cikin-gari & 202 & 25 & 196 & 24 & 118 & 15 & 80 & 10 & 108 & 14 & 100 & 12 & 804 & 100 \\
\hline $\begin{array}{l}\text { U n g u w a r } \\
\text { Sarki }\end{array}$ & 86 & 20 & 78 & 18 & 91 & 21 & 62 & 14 & 53 & 12 & 70 & 15 & 440 & 100 \\
\hline Total & 344 & 22.9 & 338 & 22.5 & 247 & 16.5 & 154 & 10.3 & 224 & 14.9 & 193 & 12.9 & 1500 & 100 \\
\hline
\end{tabular}

Source: Field survey, 2017.

Table 3: ANOVA Test Result between settlement in terms of common water sources

\begin{tabular}{lllllll}
\hline Source of Variation & SS & df & MS & F & P-value & F crit \\
\hline Between G roups & 199.667 & 5 & 39.933 & 3.803 & 0.067 & 4.387 \\
Within G roups & 63 & 6 & 10.5 & & & \\
Total & 262.666 & 11 & & & & \\
\hline
\end{tabular}

Source Data analysis, 2017

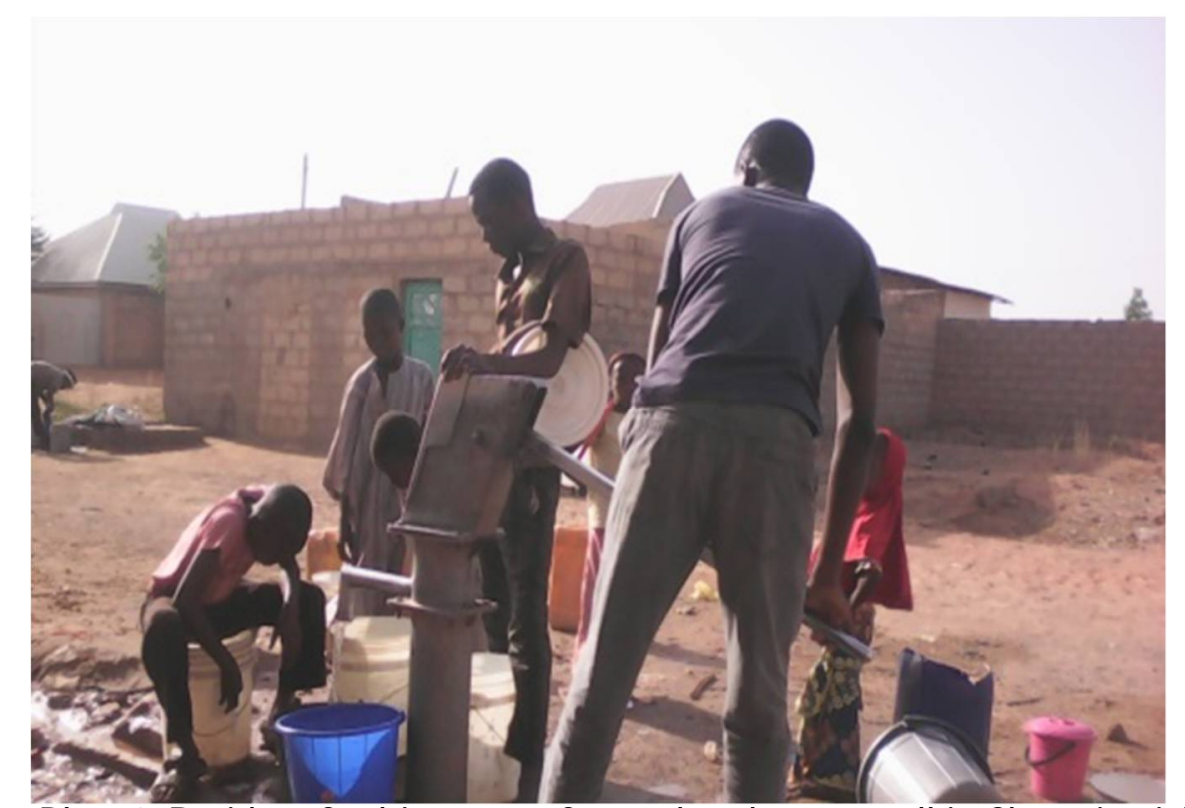

Plate 1: Resident fetching water from a hand pump well in Shagari neighbourhood, Kazaure Photography taken on the 7th of October, 2017. 
CHALLENGES AND CONSEQUENCES OF WATER SCARCITY : ...

Causes of water scarcity in the area

Research findings showed that (40\%) of the respondents in the area attributed inadequacy of water to reduction in the number of rainy season Months and the rainfall variability which have left rivers dry for most part of the year, which they attributed to climate change. Thirty five percent attributed the inadequacy to inability of the government in providing water for the citizenry, and $25 \%$ to rapid population growth, due to increase in the intake of both students and lecturers by the Hussaini Adamu Federal Polytechnic (Table 4). This is in conformity with observation made by Oluwa (2012) that the near collapse of public infrastructure in Nigeria including water is occasioned by many years of neglect by the government, lack of maintenance culture and effective planning.

Table 4: Responses on causes of the water scarcity

\begin{tabular}{lll}
\hline Causes of water Scarcity & Responses & Percentages \\
\hline Climate Change & 601 & 40 \\
Nonchalant of government to provide & 523 & 35 \\
water & 376 & 25 \\
Population growth of the Town & 1500 & 100 \\
Total & & \\
\hline
\end{tabular}

Source: Field survey, 2017

E ffect of Water Scarcity on Farming Activities

Results on the effect of water scarcity to farming showed that $20 \%$ of the respondents indicated that they have relocated their farmland to another area where water was still flowing into the streams for 6 months within the year, while others have relocated their farm land and agricultural activities close to the Mohammed Ayuba dam that cuts across the town at various points (Table 5).

They attributed their movement to the adverse effect of water scarcity on their farming activities, especially during the dry season resulting in stunted growth, shrinking leaving and leaves turning brown. In fact there could be no harvest and even where there was, there could be decrease in yield as the scarcity could last for more than 6 months in a year. Fourteen percent of the respondents have relocated their farmland to a leased site at the rate of $\mathrm{N} \mathrm{30,000.00} \mathrm{and}$ above per year. These leased farm lands were close to the dam. The respondents claimed their profit margin has dropped compared to when they were originally on their own farm land; $53 \%$ of the respondents attributed inadequate water as reason for stopping dry season farming, because the water in the river dries up for 6 - 8 months and most recently the rivers became dry just on the onset of the dry seasons in October. This gives no option for irrigation because the farm lands aren't near the Mohammed Ayuba dam or close to any river that flows during the dry season. This the respondents said have led to the loss of more than $45 \%$ of their income during dry season. However, on a new cop- 
*1A. I. ALI AND 2T. Y. RIILWANU

ping strategy which is been adopted by lem of Fulani cattle raiders has increased due some of the farmers who have enough to their search for water and greener pasture money $20 \%$ of the respondents claimed is thereby leading to frequent clashes these farm land relocation to areas where government has provided dams. Analysis of data obtained from the field revealed another negative effect of water scarcity which was however noted by all the respondents. Twenty- seven percent noted that the probdays (Table 5). Also, the problem of free grazing of goats and other livestock has increased as their owners now allow them to fend for themselves particularly for drinking water. This has led to increase in the destruction of people's crops in the farmlands.

Table 5: Responses on negative effects of water scarcity in farming activities

\begin{tabular}{lll}
\hline Negative Effects & Respondents & Percentages \\
\hline Farm Land relocation & 300 & 20 \\
Stoppage in dry season farming & 795 & 53 \\
Cattle / Famers Clashes & 405 & 27 \\
Total & 1500 & 100 \\
\hline
\end{tabular}

Source: Field survey, 2017

Effect of Water Scarcity on Fishing Ac- tion in their daily catch (Table 6). tivities

Result shows that forty-five percent (45\%) of the respondents claimed that water scarcity has led to many of the fishermen abandoning fishing for other economic activities. Analysis of data obtained from the field revealed that, the fishermen have abandoned their job for a better income generating activities, due to the streams and rivers drying up for most part of the year, invariably incapacitating their fishing activities, leading to financial lost. Evidently, a sizeable number $(15 \%)$ of the respondents make use of the dam which is the only source for fishing, and has been overstretched to the extent that even the fishermen had noticed reduc-

On the variety or species of fish been caught, a respondent was of the view that there were many types of fishes that were been caught in the different rivers that flow across Kazaure town, but with the water scarcity that has reduced fishing to the Mohammed Ayuba dam, there is only 2 types of fishes being caught Tilapia (Oreochromisnildias) and Cat Fishes (Silunifomes silures). Also $35 \%$ of the fishermen have resorted to part time fishing as a coping strategy since the income from the full time fishing is no longer sustainable. Five percent indicated a reversal to fishing ponds as a coping strategy (Table 6). 
CHALLENGES AND CONSEQUENCES OF WATER SCARCITY : ...

Table 6: Distribution of respondents by the effect of water scarcity on fishing activities

\begin{tabular}{lll}
\hline Fishing Activities & Respondents & Percentages \\
\hline People abandoned Fishing & 675 & 45 \\
Making use of D am & 225 & 15 \\
Part Fisher men & 525 & 35 \\
Pond users & 75 & 5 \\
Total & 1500 & 100 \\
\hline
\end{tabular}

Source: Field survey, 2017

\section{Agents of water provision}

Results indicated that $56.5 \%$ of the water sources are built by individuals or community members followed by private partners $(23.2 \%)$ and is government with $20.3 \%$ (Table 7). Already, literature maintains that majority of Nigerians depends on selfefforts in meeting their daily water and sanitation needs (Akpabio, 2012). About 80\% of the respondents realised that government intervention in the provision of safe water, obviously, government at the state and local levels could not satisfy the safe water needs of their citizenry. Water supply facilities provided by government in the area were in a state of disrepair, perhaps due to lack of maintenance that is even why fishermen and water collectors share the same water body (Plate 2).

Table 7: Responses on the agencies that provide water

\begin{tabular}{lll}
\hline Agencies & Respondents & Percentages \\
\hline Individual effort/community & 847 & 56.5 \\
Private partners & 348 & 23.2 \\
G overnment agencies & 305 & 20.3 \\
Total & $\mathbf{1 5 0 0}$ & $\mathbf{1 0 0}$ \\
\hline
\end{tabular}

Source Field survey, 2017 


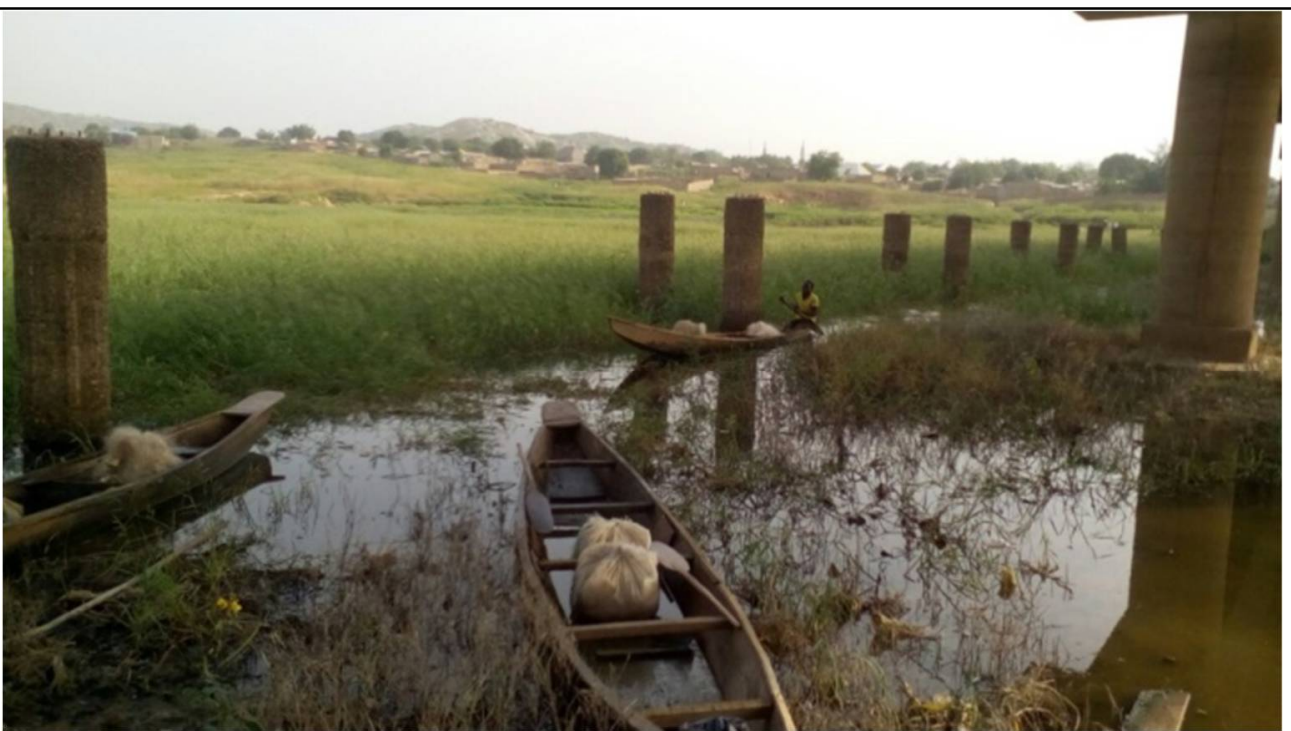

Plate 2: Ayuba dam with fishing activities photography taken on the 7th of 0 ctober, 2017

From the result of check list, it was revealed that there were twenty (20) privately commercially owned boreholes, sixty (60) hand pump boreholes and ten (10) modern grouted wells in Kazaure. These indicated that most of the facilities were inadequate in the area (Table 8 and Plate 3). This is supported by the assertion of (Lawal and Basorun, 2015) that in Akure the current data on water facilities obtained from the Water Board revealed that Ijapo Estate has 1 solarpowered borehole, Shagari Village, 2; O keO gba, 1; and Apatapiti/ Alaba layout 1. Out of these four locations, Ijapo estate has been provided with water reticulation networks while the rest have none and these facilities, no doubt, were inadequate to cater for the teeming inhabitants of the rapidly growing city. The ANOVA test shows that there is significant difference between the settlements in terms of water facility type at 0.05 level of significant whereby $p$ value is 0.046 with $F$ value of 5.316 and F critical is 5.143253 (Table 9). This finding is substantiated by that of Tyler, Joshua, Rebecca, Arabi, and Jiyoung (2017) there that there is significant difference among rural communities in terms of the distribution of water, heath and sanitation facilities. This might affect policy marking that is associated with water provision in the area.

Table 8: D istributions of water facilities in Kazaure

\begin{tabular}{lllll}
\hline Settlements & \multicolumn{3}{c}{ Water Facilities Type } \\
& $\begin{array}{l}\text { Privately commencially } \\
\text { owned boreholes }\end{array}$ & $\begin{array}{l}\text { Hand pump } \\
\text { boreholes }\end{array}$ & $\begin{array}{l}\text { Modem } \\
\text { wells }\end{array}$ & grouted \\
\hline Kanti & 15 & 11 & 1 \\
Cikin-gari & 3 & 28 & 3 \\
Ungunwar Sariki & 2 & 21 & 6 \\
Total & 20 & 60 & 10 \\
\hline
\end{tabular}

Source: Field survey, 2017 
CHALLENGES AND CONSEQUENCES OF WATER SCARCITY : ...

Table 9: ANOVA test result Single factor between settlements in terms of water facility type

\begin{tabular}{lrrrrrr}
\hline Source of Variation & \multicolumn{1}{c}{ SS } & df & MS & F & P-value & F crit \\
\hline Between Groups & 466.666 & 2 & 233.333 & 5.316 & 0.046 & 5.143 \\
Within G roups & 263.333 & 6 & 43.888 & & & \\
Total & 730 & 8 & & & & \\
\hline
\end{tabular}

Source D ata analysis, 2017

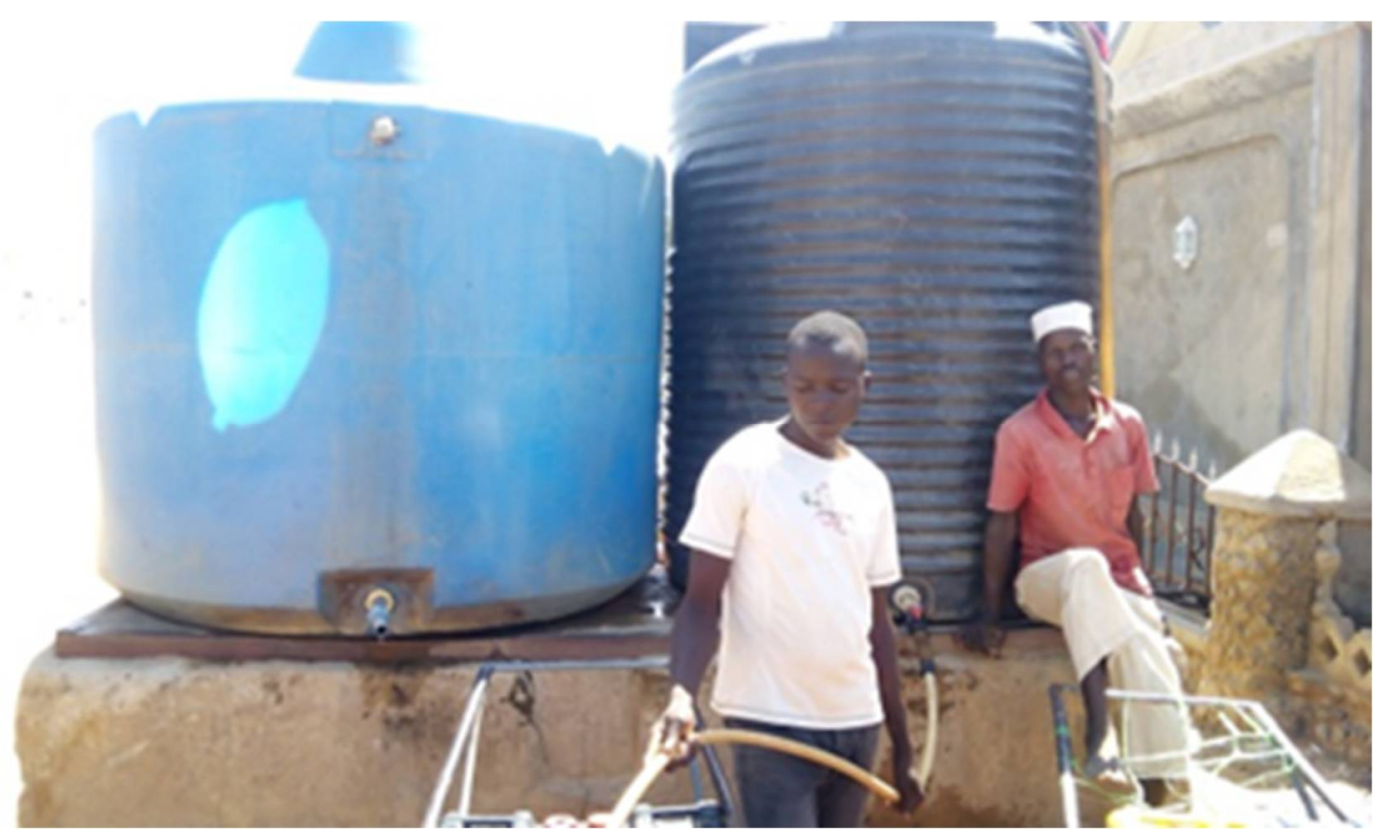

Plate 3: Private water supply service for private and public neighbourhoods of Kazaure Photography taken on the 7th of October, 2017.

\section{CONCLUSION}

The study established that hand pump wells appears to be the predominant source of water supply to the teeming residents and most people in Kazaure purchased water from vendors. It was deduced that there is no significant difference between the settlements (Kanti, Cikin-gari and Unguwarsarki) in terms of common water sources. Research findings showed that most of the respondents in the area attributed inadequa- cy of water to reduction in the number of rainy season Months and the rainfall variability which have left rivers dried for most part of the year, which they attributed to climate change.

The study established that water scarcity resulted the movement of farmers from one place to another during dry season and most of the respondents attributed inadequate water as reason for stopping dry season farming 
in the area. The study proved that most of the respondents claimed that water scarcity has led to many of the fishermen in the area abandoned fishing for other economic activities. It was further established that most of the water sources are built by individuals for commercial purpose and through community services and there are more hand pump boreholes than any other type in the area. The study also established that there is significant difference between the settlements (Kanti, Cikin-gari and Unguwarsarki) in terms of water facility type which might affect policy marking regarding water provision in the area.

\section{RECOMMENDATIONS}

With particular reference to the findings the study recommends that there is the need for the community members to establish public private partnership regarding water supply in the area to reduce purchase of water. Likewise private sectors should be encouraged to pool resources together to provide and improve water supply projects for effective water supply. The study also recommends that both state and local government should provide more mechanical powered bore holes in the areas to minimise the water shortage and there should be equal distribution among the major quarters in the town. The study recommends further that state and federal government should dredge the only existing Ayuba dam in the area in order to improve on fishing and irrigation. It was recommended further that a water treatment plant should be provided in the Ayuba dam to improve water supply in the area for development.

\section{REFERENCES}

Abubakar, M. K., Aminu, M. M., Abba, A., Sani, I. 2015. Phytoplankton Survey and Physico-chemical Assessment of Kazaure D am, Nigeria. Procedings of ThdRES 3rdInternational Conference, Dubai, UAE, 4th July 2015, ISBN: 978-93-85465-46-8.

Aderinto, S. 0. 2018. GunsandSocidyinCo lanial Nigria. Indiana University Press Limited.

Akpabio, E. M. 2012 Water Supply and Sanitation Services Sector in Nigeria: The Policy Trend and Practice Constraints. Center for Dedepment Research, University of Bonn WorkingPaper Series 96. ISSN 1864-6638

Arlosorof, S., Gerhard, T., David, W., Andrew, K .L. Otto, L, Robered, R. 1987. Commmity Water Supply. Thehand pumps qption; the World Bank Washington DC 1987.

Ayodele, A. 2000. Kazaure Emiraté Ibadan (Nigria). Nigeian Traditional States Wodd State ment. Ben Cahoon limited

Basonun J.0., Lawal O.L (2015). Access To Safe Water In Akure: A Paradox In Nigerian Urbanized Regions" Intemational Jaumal of EmagingKnowiedge 3(3): 39 - 45.

Danbatta, U.A 2009. On the Evolution of the Kazaure Schist Belt of NW Nigeria: A Re-interpretation. Gldbal Jaumal Geological Saences8(2):207-216.

Gusikit, R.B., Lar U.A 2014. Water Scarcity and the impending Water related Conflicts in Nigeria: A Re appraisal". Joumal of Enironmental Saience Toxicology and Food Tedndog. 8 (11): 44 - 56.

Idowu, D. L 2017. Causes, Consequences 
CHALLENGES AND CONSEQUENCES OF WATER SCARCITY : ...

and Resolution Of Environmental Conflict In Nigeria". Intemational Jaumal of Soial Saence and Economic Rearth ISSN: 2455-8834 Vdume 02, Issue 01

Ishaku, H.T, Rafee, M. M., Ajayi, A.P. and Hanuna, A. 2011. Water Supply Dilemma in Nigeria Rural Communities: Looking towards the sky for an answer. A jamal of nater Resarce and protetion Vol.3: $598-606$.

Isma'il, M., Salisu, A., Yusuf, S., Muhammad, Z.D 2013. Spatial analysis of Urban G rowth in Kazaure Local Government, Jigawa State. Intemational Jamal of Geematics andGeoscienes ISSN-0976-4380. 4(1):47-60

Kelechi, I. L. 2012. The Rdationship between Water Scarity A wareness by Transnational Nige nians and its Effeets on theWillingess to Contrib utetoWater Scarcity Reief effats in Nigria An un published thesis at College of Community health University of ILLinois at Urbanachampaign.

Krejcie, R.V., Morgan, D.W. 1970. D etermining sample size for research activities, educational and psychological measurement. 30. 607- 610 .

Lawal, O.L., Basonun, J.0 2015. Access to Safe Water in Akure: A Paradox in Nigerian Urbanized Regions. Intemational Jamel of EnrigingKnowkeabe, 3(3): 39 - 45.

Mancosu, N., Richard L. S., Gavriil, K. and Donatella, S. 2015. Review Water Scarcity and Future Challenges for Food Production. WaterJaumal.7:975-992.

Momison, J., Monikawa, M., Murphy, M., Schulte, P. 2009 Water Scarcity and Climate Change: Growing Risks for Busi- nesses and Investors. A Ceres Repart. Pacific Institute United State.

National Bureau of Statistics (NBS). 2017. Statistical Report on Women and Men in Nigeria 2017. Social Statistics Report 201. www.nigerianstat.gov.ng/

Oluwa, K. 2012. Infrastructure Development: Catalyst for economic growth'. The Businessday, online edition.

Raunio, S. 2016. Successful implementation of Public-Private Partnerships to local communities providing water supply services in Sub-Saharan Africa. Helsinki Metropolia University of Applied Sciences Bachelor of Business Administration European Business Administration Thesis 16.9.2016.

Rilwanu, T. Y., Iguisi, E.0., Mallam, I. 2016. Assessment of Water Supply Situation in the Rural Areas of Kano State, Northern Nigeria". Gldbal Adsanced Reserrch Jaumal of Agiaultural Saieme (ISSN: 2315-5094) Vd. 5 (1): 033-041, January, 2016 Issue Available olinehtp/ / gaj.org/ garjas/ home

Sandra, L., Postel, B.H., Thompson J. 2005. Watershed protection: Capturing the benefits of nature's water supply services". A United Nations Sustainable Development Journal, Vol 29, Issue 2, 2005, Pp 98 - 108.

Szentes, G. 2009. Granitefomationandganite cavities in Nathem Niggia: Cad.Lab. Laxe34 P13 - 26.

Showers, K. B. 2002. Water scarcity and urban Africa: An overview of Urban-Rural water linkages". WoddDeddqpment, 30(4): 621 $-648$.

Sunday, D. A. 2015. Fresh water Scarcity 
*1A. I. ALI AND 2T. Y. RIILWANU

induced Conflicts between Farmers and Enwron ResPublicHelth 14(4): 441.

Pastoralists_in Northern Nigeria”. A Re

search and Intemational Cocperation Initiative 2 World Wild Life' 2013. Water Scarcity threats (8): 67- 79.

Retrieved 20 October 2013.

Tyler, G., Joshua, Y., Rebecca, G., Ara- Wilhite, D.A 2005. Drangt andWater Crises bi, M., Jiyoung L. 2017. Water Access, Saiene, TehndogyandManagement Issues". CRC Sanitation, and Hygiene Conditions and Press, Taylor and Francis Group 6000 BroHealth Outcomes among Two Settlement ken Sound Parkway NW 300 Pp 33 Types in Rural Far North Cameroon. IntJ

(Manuscript reecived: 3rdApril, 2018; accepted: 14th March, 2019). 